\title{
MERANIE PRIESTOROVEJ DOSTUPNOSTI PÔŠT NA ÚZEMÍ MESTA BRATISLAVA (KVANTITATÍVNY PRÍSTUP)
}

\author{
František Križan *, Ladislav Tolmáči**
}

\section{Úvod}

Tento príspevok nadväzuje na štúdiu [7], ktorá sa zaoberala zhodnotením priestorovej dostupnosti pôšt na území mesta Bratislava kvalitatívnym prístupom. Aplikáciou dvoch percepčných mier dostupnosti boli identifikované regióny s priaznivými, resp. menej priaznivými hodnotami priestorovej dostupnosti pôšt. Percepcie respondentov ako miery dostupnosti boli hodnotené v rámci automobilovej siete, siete mestskej hromadnej dopravy a siete pre chodcov.

Ciel'om tohto príspevku je zhodnotenie dostupnosti pôšt na územní mesta Bratislava dvoma kvantitatívnymi mierami dostupnosti v sieti mestskej hromadnej dopravy. V nasledujúcom odseku sú prediskutované aplikované metódy a dáta. Ďalej nasleduje analytická čast' zaoberajúca sa meraním dostupnosti pôšt aplikáciou dvoch mier priestorovej dostupnosti. V záverečnej časti je priestor venovaný krátkej diskusii k danej problematike a získaným výsledkom.

\section{Metódy a dáta}

Dostupnost' možno merat' pomocou mier dostupnosti. L. Tolmáči [14, s. 8] rozdel'uje miery dostupnosti do piatich vel'kých nedisjunktných skupín:

1. Miery zamerané na prepojenie skúmaných uzlov s ostatnými uzlami v skúmanej sieti v zmysle kvantitatívnych alebo kvalitatívnych charakteristík, akými sú napr. počty zastávok a i.

2. Miery dostupnosti kumulujúce kvantitatívne charakteristiky ako napr. vzdialenost', čas alebo sú vyjadrené monetárne, čím sa vyjadrí pozícia uzla voči ostatným uzlom v skúmanej dopravnej sieti.

3. Miery dostupnosti založené na gravitačných modeloch.

4. Miery dostupnosti založené na teórii náhodného úžitku, ktorými sa stanovuje pravdepodobnost' výberu daného uzla k relatívnej pravdepodobnosti z danej množiny uzlov.

5. Miery dostupnosti vyjadrujúce relatívne priestorové usporiadanie vymedzeného regiónu.

Alternatívnu klasifikáciu uvádza D. Michniak [11, s. 15], ktorý metódy merania dostupnosti rozdel'uje do dvoch skupín. V prvom prípade ide o miery založené na cestovnom správaní a miery založené na mapovaní priestorových možností, ktoré neobsahujú žiadnu funkciu reprezentujúcu správanie. V druhom prípade ide o miery obsahujúce predpoklad, že

\footnotetext{
* Mgr. František Križan, PhD., Katedra regionálnej geografie, ochrany a plánovania krajiny, Prírodovedecká fakulta UK Bratislava, Mlynská dolina 84215 Bratislava, email: krizan@fns.uniba.sk

** doc. RNDr. Ladislav Tolmáči, PhD., Katedra regionálnej geografie, ochrany a plánovania krajiny, Prírodovedecká fakulta UK Bratislava, Mlynská dolina 84215 Bratislava, email: tolmaci@fns.uniba.sk
} 
s rastúcou vzdialenost'ou klesá priestorová interakcia alebo miery, ktoré tento predpoklad neobsahujú.

Z vel'kého množstva mier dostupnosti $[2,12,14]$ boli v príspevku aplikované dve miery dostupnosti:

Dst1. Binárna dostupnost' vyjadruje kvantitatívny údaj o vzdialenosti, časovej či finančnej dosiahnutel'nosti uzla $i$ z iného uzla $j \mathrm{v}$ danej sieti:

$\operatorname{Dst~}_{i}=d_{i j}$

kde $d_{i j}$ je vzdialenost' medzi východiskovým $i$ (UO) a ciel'ovým $j$ (pošta) uzlom.

Vzdialenost' $\left(d_{i j}\right)$ môže byt' vyjadrená aj prepravným časom, cestovnými nákladmi a pod. Najčastejšie používanými meraniami sú rôzne typy vzdialeností (Euklidovská, Manhattanská a i.) alebo cestovný čas, ktorý viacerí autori preferujú a považujú ho v porovnaní s meraním vzdialenosti za viac informatívny [15, s. 664]. Dostupnost' možno merat' z jednotlivých rezidencií alebo z geometrického (či iného) centra jednotlivých štatistických regiónov. Meranie možno uskutočnit prípadne aj z najbližšej MHD zastávky, aby naozaj platilo $d_{i j}=$ minimum, avšak vzhl'adom na heterogenitu UO bolo potrebné merat' binárnu dostupnost' nielen $\mathrm{v}$ sieti $\mathrm{MHD}$, ale aj $\mathrm{v}$ sieti pre chodcov, pretože $\mathrm{k}$ danej vzdialenosti (času) medzi východiskovou a ciel'ovou zastávkou bolo nutné pripočítat' aj vzdialenost' (čas) potrebný na dosiahnutie východiskovej zastávky a na druhej strane vzdialenost' (čas) potrebný na dosiahnutie ciel'ového uzla z ciel'ovej zastávky. Preto bola binárna dostupnost' $\left(\right.$ Dst $\left._{\mathrm{i}}\right)$ meraná ako:

$\operatorname{Dst} 1_{i}=d_{i a}+d_{a b}+d_{b j}$

kde $d_{i a}$ je vzdialenost' medzi východiskovým uzlom (rezidencia) a východiskovou zastávkou, $d_{a b}$ je vzdialenost' medzi východiskovou a ciel'ovou zastávkou,

$d_{b j}$ je vzdialenost' medzi ciel'ovou zastávkou a ciel'ovým uzlom (poštou).

Vzdialenost' medzi východiskovým uzlom a zastávkou $\left(d_{i a}\right)$ bola meraná ako priemerná vzdialenost' z domu k najbližšej MHD zastávke z dotazníkového prieskumu [6]. Vzdialenost' $d_{a b}$ bola meraná v sieti MHD. Hodnoty pre $d_{a b}$ boli merané v sieti pre chodcov pohybujúc sa priemernou rýchlost'ou $5 \mathrm{~km} \cdot \mathrm{h}^{-1}$ od ciel'ovej zastávky po vchod do ciel'ového uzla (pošty), pričom sa vychádzalo z priemernej vzdialenosti medzi zastávkami v oboch smeroch.

Dst2. Miera založená na príležitostiach kvantifikuje množstvo príležitostí (pôšt) dostupných v rámci istej vzdialenosti (času transportu) z daného uzla. Čiže aktivity $k$ pre jednotlivca $\mathrm{z}$ miesta $i$ používajúc dopravnú siet' $l$ možno vyjadrit' pomocou formuly [5]:

$D_{s t} 4_{i k l}=\sum_{j \in M_{i k l}} O_{j k}$

kde:

$D s t_{i k l}$ je dostupnost' jednotlivca $i$ alebo regiónu $i$ čo sa týka aktivity $k$ a dopravnej siete $l$,

$O_{j k}$ je počet príležitostí (oportunities) pre aktivitu $k \mathrm{v}$ mieste $j$,

$M_{i k l}=\left\{j \mid d_{i j l}<s_{k l}\right\}$ set aktivít v uzloch považovaných za dostupné,

$d_{i j l}$ je vzdialenost', cestovný čas alebo iná miera námahy oddel'ujúca $i$ a $j$ od jednotlivca v dopravnej sieti $l$,

$s_{k l}$ je maximálna vzdialenost' alebo rozsah (vyjadrený v km alebo časovo), v ktorom sú dané aktivity dostupné v rámci dopravnej siete $l$.

Pri analýze sa vychádzalo zo vzdialenosti do $30 \min ^{1}$, ktorá je aj mapovo znázornená. V podobe grafu sú dokumentované aj vzdialenosti 10 a 20 min. Analýza prebiehala v programe ArcGIS (9.1), v ktorom boli zhotovené aj mapové výstupy.

\footnotetext{
${ }^{1}$ Vzdialenost' do 30 min znamená hornú hranicu cestovného času, do ktorého je cestujúci schopný dosiahnut' danú poštu vychádzajúc z Dst1.
} 
Objektom výskumu boli urbanistické obvody (UO). Z celkového počtu 263 UO je až 46 UO (17,5 \%) neobývaných. Analyzovaných bolo celkovo $131 \mathrm{UO}$, v ktorých žije 500 a viac obyvatel'ov. Analyzované UO predstavujú 49,8 \% všetkých UO, avšak žije v nich až $98,1 \%$ populácie mesta.

Analyzovanou dopravnou siet'ou bola siet' mestskej hromadnej dopravy (MHD). Dáta o jednotlivých spojoch pochádzajú z grafikonu MHD a vyhodnocované boli pomocou programu Cestovné poriadky 2003/2004 od firmy Inprop s.r.o. ${ }^{2}$ s aktualizáciou ku dňu výskumu. Pri analýze boli v programe zohl'adnené všetky limitujúce faktory.

Pri meraní dostupnosti sa vyskytlo niekol'ko faktorov, ktoré možno považovat' za limitujúce. V prvom rade je to lokalizácia zastávok v danom UO. Nie všetky skúmané UO majú na svojom území zastávku MHD. V takom prípade bola analyzovaná najbližšia zastávka v susednom UO, resp. zastávka zvolená respondentmi žijúcimi v danom UO. Názvy takýchto zastávok boli získané pri dotazníkovom výskume v týchto UO [6]. Ďalším limitujúcim faktorom boli prestupy, čiže ak bolo treba prestupovat' viac ako 2-krát, daný uzol sa považoval za nedostupný. Analýza prebiehala v pracovný deň 06. júna 2006 o $8.00 \mathrm{~h}$ s platnými dopravnými obmedzeniami v tento deň, pričom do analýzy neboli zahrnuté nočné spoje.

Ďalším problémom v súvislosti so vzdialenost'ou vyskytujúcim sa pri výskume dostupnosti je, že vzdialenost' z uzla $i$ do uzla $j$ nemusí byt' komutatívna, čiže vzdialenost' $\mathrm{z} i$ do $j$ sa nerovná vzdialenosti $\mathrm{z} j$ do $i$, či už ide o fyzickú, relatívnu, časovú alebo inú vzdialenost'. Na takto chápanú vzdialenost' je nutné brat' ohl'ad najmä v rámci najmenších jednotiek (intraurbánna dostupnost'), ked' spomínaná komutatívnost' môže súvisiet' napr. s jednosmernými cestami, dopravnými zápchami v rannej špičke, čím sa cestovná vzdialenost' automaticky predlžuje. Vo všeobecnosti možno hovorit' o zdrojových a ciel'ových mierach dostupnosti [4]. Kým zdrojové miery dostupnosti vyjadrujú l'ahkost', s akou možno dosiahnut' príležitosti (access to), ciel'ové miery dostupnosti vyjadrujú l'ahkost', s akou môžu byt' miesta určenia dosiahnuté (access of). Takto definovanú vzdialenost' (dostupnost'), vychádzajúc z práce [9], možno chápat' duálne (obr. 1). Na jednej strane si možno položit' otázku: „Odkial' cestujúci prichádza?“( (obr. 1a) alebo na druhej strane: „Kam cestujúci smeruje?“(obr. 1b). Pri výskume bol aplikovaný variant „odkial' cestujúci prichádza?“, čo možno nazvat’ i ako zdrojové meranie dostupnosti.
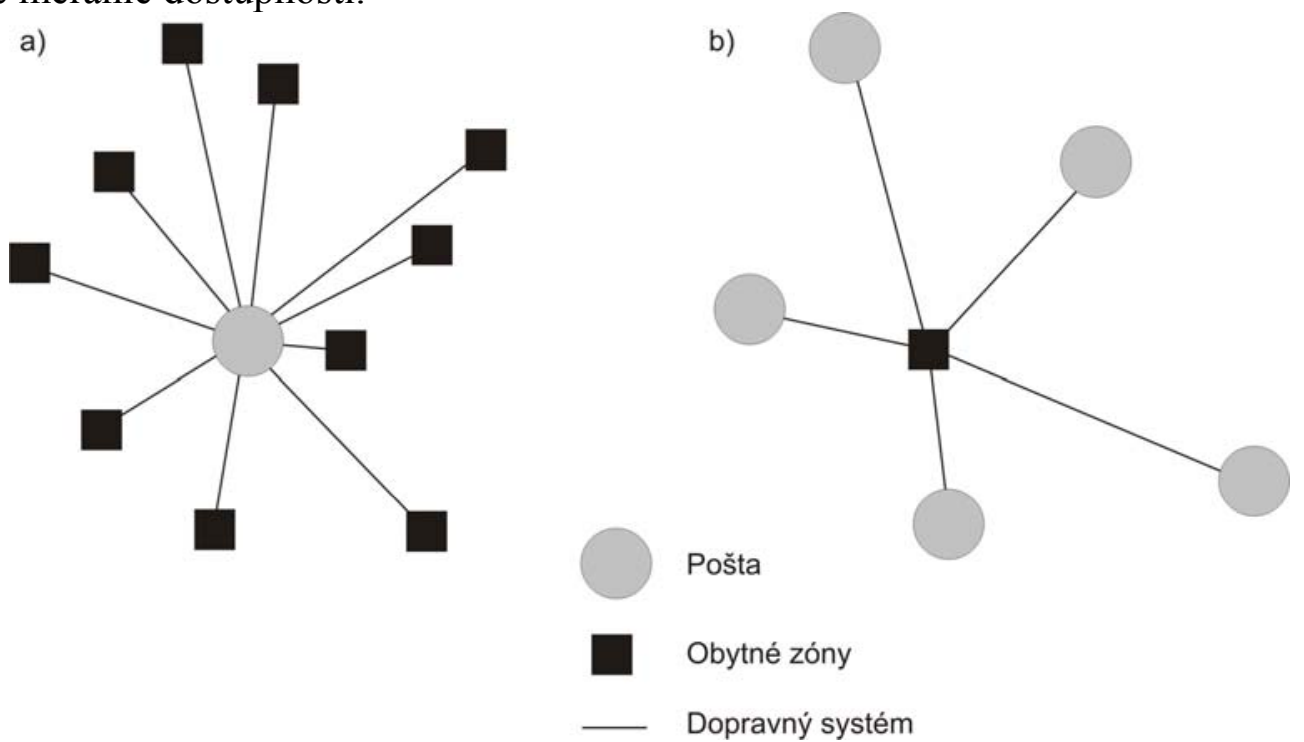

Obr. 1. Možnosti štúdia dostupnosti. Zdroj: upravené podl’a [9].

\footnotetext{
${ }^{2}$ Vol'ne prístupný na http://www.inprop.sk/
} 


\section{Analýza}

V Bratislave bolo v roku 2006 lokalizovaných 49 pôšt nerovnomerne rozložených na území mesta (obr. 1). Analyzovaných bolo 47 pôšt, pretože 3 pošty sídlia na rovnakej adrese (Tomášikova 54) a pri analýze boli považované za jeden objekt.

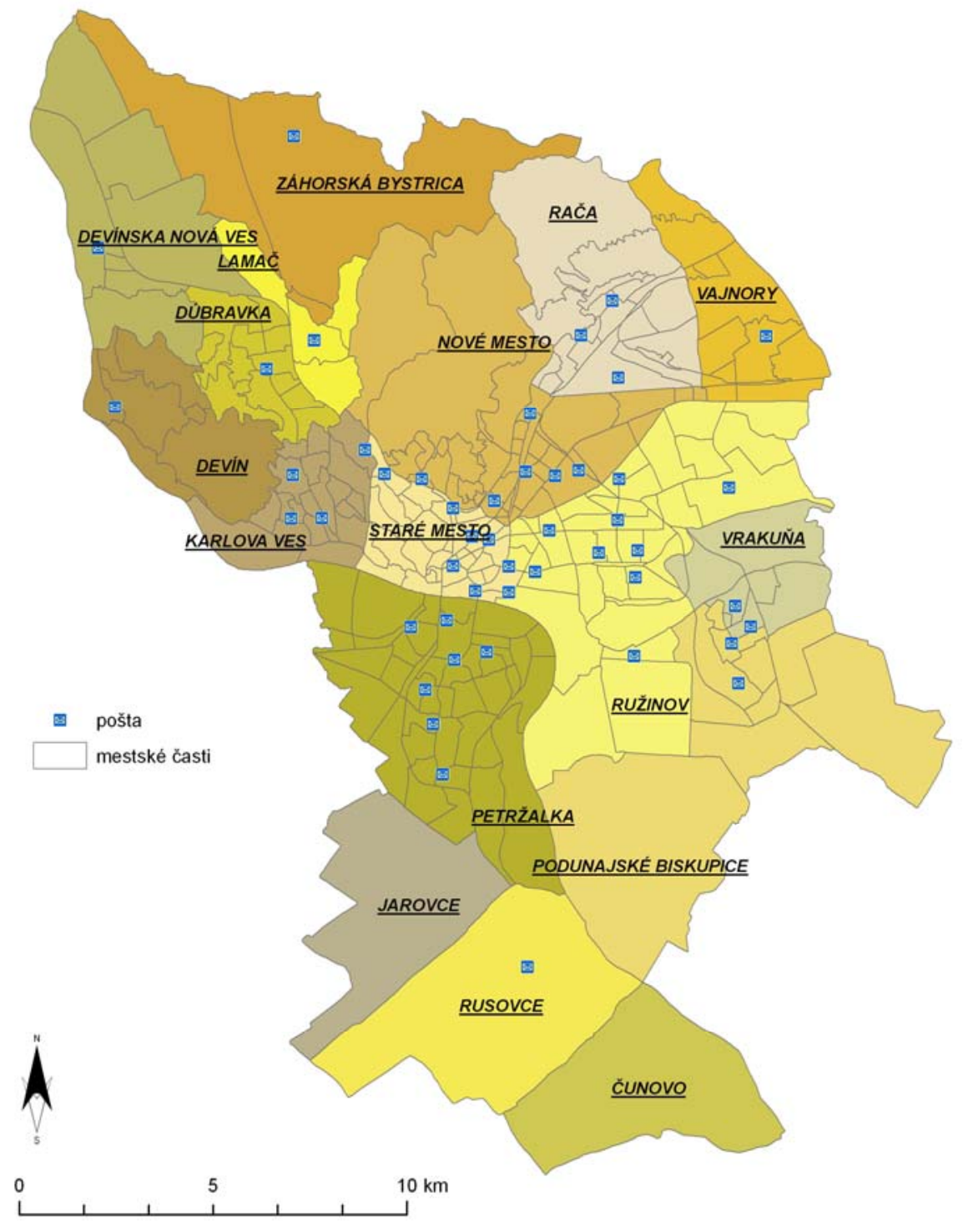

Obr. 2. Lokalizácia pôšt na území mesta.

Výsledky merania dostupnosti pre Dst1 dokumentujú obr. 3 a tab. 1. Kategória do 5,0 min predstavuje kategóriu s najpriaznivejšími hodnotami dostupnosti pôšt v sieti MHD. Celkovo sem spadá 14,5 \% skúmaných UO, v ktorých žije 18,1 \% obyvatel'ov mesta (tab. 1). Najnižšia hodnota $(3,4 \mathrm{~min})$ bola nameraná $\mathrm{v}$ prípade UO Justičný palác. Z priestorového hl'adiska (obr. 3) ide najmä o obvody z mestskej časti (MČ) Staré Mesto (5 UO) a Petržalka (5 UO). Ďalej sem patria aj obvody z MČ Ružinov (3 UO), Nové Mesto (2 UO), Karlova Ves (1 UO), Vrakuňa (1 UO), Podunajské Biskupice (1 UO) a Devín (1 UO).

Jednoznačne najpočetnejšie zoskupenie obvodov predstavuje kategória 5,1 až 10,0 min. Vzhl'adom na svoju početnost' ide o heterogénnu skupinu obvodov lokalizovaných takmer vo všetkých MČ od centra mesta (Staré Mesto) až po periférne časti (Vajnory, Záhorská Bystrica, Rusovce a i.). Relatívny podiel obvodov (ako aj obyvatel'ov) dosahuje viac ako $60 \%$. 
Druhú najpočetnejšiu skupinu UO zastupuje kategória 10,1 až 15,0 min. Priestorové rozloženie daných UO zasahuje takmer výlučne severnú čast' územia mesta Bratislava. Z južnej časti mesta (MČ Petržalka) sem patria 2 UO lokalizované v okrajových zónach obytnej plochy sídliska.

Posledné dve kategórie združujú iba 3 UO, v ktorých žije 4,5\% obyvatel'ov Bratislavy. Patria sem jednak centrálne lokalizované obvody (Matúškova ul. a Koliba) z MČ Nové Mesto, ako aj periférne lokalizovaný obvod Čunovo, v prípade ktorého bola nameraná aj najmenej priaznivá hodnota dostupnosti pôšt v sieti MHD (24,7 min).

Tab.1. Vybrané ukazovatele dostupnosti pôšt podl'a Dst1.

\begin{tabular}{lrrrr}
\hline \multirow{2}{*}{ Kategória } & \multicolumn{2}{c}{ Počet UO } & \multicolumn{2}{c}{ Počet obyvatel'ov } \\
\cline { 2 - 5 } & absolútny & \multicolumn{1}{c}{ relatívny* } & absolútny & relatívny** \\
\hline do 5,0 min & 19 & $14,5 \%$ & 77419 & $18,1 \%$ \\
5,1 až 10,0 min & 81 & $61,8 \%$ & 269345 & $62,8 \%$ \\
10,1 až 15,0 min & 28 & $21,4 \%$ & 71002 & $16,6 \%$ \\
15,1 až 20,0 min & 2 & $1,5 \%$ & 1824 & $4,3 \%$ \\
nad 20,0 min & 1 & $0,8 \%$ & 911 & $0,2 \%$ \\
\hline
\end{tabular}

*relatívny počet zo skúmaných urbanistických obvodov (131), **relatívny počet zo všetkých obyvatel'ov mesta (428 672).

Pri aplikácii miery založenej na príležitostiach (Dst2) sa preukázala poddimenzovanost' MČ Rača vzhl'adom na fakt, že v tejto MČ sa nachádza až 7 UO patriacich do kategórie vyznačujúcou sa najmenej priaznivou dostupnost'ou pôšt (kategória do 10 pôšt). Okrem toho sem patria aj d'alšie periférne obvody (obr. 4) ako Cunovo, Devínska Nová Ves, Záhorská Bystrica, ale aj centrálne lokalizovaný obvod Bôrik (MČ Staré Mesto). V prípade UO Pri Šajbách a Čunovo bola nameraná najmenej priaznivá hodnota pri aplikácii Dst2. Do vzdialenosti $30 \mathrm{~min}$ v sieti MHD je ztýchto UO dostupná iba jedna z analyzovaných poštových prevádzok.

Zvyšok periférne lokalizovaných obvodov patrí do kategórie 11 až 20 dostupných pôšt do vzdialenosti 30 min. Celkovo sem spadá až 22 UO s podielom obyvatel'ov 21,2 \% (tab. 2). Väčšinový podiel obvodov v danej MČ bol zaznamenaný v MČ Dúbravka.

Tab.2. Vybrané ukazovatele dostupnosti pôšt podl'a Dst2.

\begin{tabular}{lrrrr}
\hline \multirow{2}{*}{ Kategória } & \multicolumn{2}{c}{ Počet UO } & \multicolumn{2}{c}{ Počet obyvatel'ov } \\
\cline { 2 - 5 } & absolútny & relatívny* & absolútny & relatívny** \\
\hline do 10 pôšt & 17 & $13,0 \%$ & 33964 & $7,9 \%$ \\
11 až 20 pôšt & 22 & $16,8 \%$ & 90898 & $21,2 \%$ \\
21 až 30 pôšt & 29 & $22,1 \%$ & 95160 & $22,2 \%$ \\
31 až 40 pôšt & 53 & $40,5 \%$ & 182248 & $42,5 \%$ \\
nad 40 pôšt & 10 & $7,6 \%$ & 18231 & $4,3 \%$ \\
\hline
\end{tabular}

*relatívny počet zo skúmaných urbanistických obvodov (131), **relatívny počet zo všetkých obyvatel'ov mesta (428 672).

Vnútorný prstenec predchádzajúcej kategórie (11 až 20 pôšt) smerujúci do centra mesta tvorí d'alšia kategória (21 až 30 pôšt). V týchto obvodoch býva vyše 95000 obyvatel'ov. Kompaktnejšie zoskupenia daných obvodov možno identifikovat' v MČ Karlova Ves, kde tvoria väčšinu obvodov. Ďalej sem patrí južná čast' MČ Petržalka alebo východná čast' MČ Ružinov. 
Uzatvárajúci sa prstenec smerom do centrálnej časti mesta tvoria UO d’alšej kategórie (31 až 40 pôšt). Táto kategória zoskupuje najväčší podiel UO a žije tu najviac obyvatel'ov mesta (tab. 2). V priestore možno pozorovat' kompaktnejšie zoskupenia, ktoré sa nachádzajú výlučne iba v štyroch MČ (obr. 4). Najviac UO patrí do MČ Petržalka (15 UO). Rovnaký počet obvodov (14 UO) tejto kategórie patrí pod MČ Ružinov a Staré Mesto. Ostatné obvody patria do MČ Nové Mesto (10 UO).

Obvody vyznačujúce sa najpriaznivejšími hodnotami miery Dst2 spadajú do kategórie nad 40 dostupných pôšt do vzdialenosti 30 min v sieti MHD. Táto kategória je najmenej početnou kategóriou čo do počtu UO, ako aj počtom obyvatel'ov. Z priestorového hl'adiska ide výlučne o centrálne lokalizované UO (MČ Staré Mesto a Nové Mesto) predstavujúce jadro, ktoré obkolesujú vyššie charakterizované kategórie. Najpriaznivejšie hodnoty boli zaznamenané v prípade UO Pokrok, Unitas a Jiskrova ul. nachádzajúce sa v MČ Nové Mesto, z ktorých je do 30 min dostupných až 45 poštových prevádzok.

\section{Diskusia a záver}

Ciel'om príspevku bolo zhodnotenie priestorovej dostupnosti pôšt na území mesta Bratislava pomocou vybraných kvantitatívnych mier dostupnosti. Aplikované boli dve miery dostupnosti. Z výstupov analýz prvej z nich (Dst1) možno konštatovat', že do 10,0 min je pošta v sieti MHD dostupná pre vyše 80 \% obyvatel'ov mesta, čo možno považovat' za dostačujúce. Iba pre minimum obyvatel'ov $(4,5 \%)$ bola hodnota dostupnosti stanovená nad 15,0 min.

Binárna miera dostupnosti (Dst1) sa ukázala ako jedna z najvhodnejších a možno ju považovat' za základnú mieru, pretože viaceré iné miery vychádzajú práve z binárnej miery dostupnosti. Ako tvrdia S. Liu a X. Zhu [10, s. 49]: „každá miera dostupnosti musí v sebe zahrňovat' vzdialenost' medzi východiskovým a ciel'ovým miestom.“ Binárnu mieru dostupnosti označuje M. Guagliardo [3] ako mieru so slabou výpovednou hodnotou, avšak v kombinácii s inými mierami je nevyhnutná na pochopenie priestorovej dostupnosti. Mieru možno aplikovat' aj v územnom plánovaní ako štandard pre maximalizáciu času či vzdialenosti pri lokalizácii vybraných zariadení.

Druhou aplikovanou mierou dostupnosti bola miera založená na príležitostiach (Dst2). Za pozitívum možno považovat', že viac ako $92 \%$ obyvatel'ov mesta má do $30 \mathrm{~min}$ v sieti MHD prístup k viac ako 10 poštám. Dostupnost' iba jednej pošty do tejto vzdialenosti bola zaznamená v prípade dvoch UO (Pri Šajbách a Čunovo), čiže zo všetkých analyzovaných UO je do 30 min dostupná aspoň jedna pošta, čo možno hodnotit' kladne.

Miera založená na príležitostiach poukázala vo viacerých prípadoch na rôzne priestorové súvislosti. Graf 1 znázorňuje Dst2 pri ohraničení rôznymi vzdialenost’ami $(10,20$, 30 min). Ako možno pozorovat', celkové hodnoty vo väčšej či menšej miere varírujú. Medzi najväčšie nevýhody tejto miery teda patrí svojvol'ná vol'ba hranice skúmaných izolínií. Druhou nevýhodou je, že zlepšenie cestovného času nemusí hned' viest' k zmene indexu tejto miery dostupnosti. Príkladom je zlepšenie dostupnosti uzla z 29 min na 9 min, no v indexe zameranom na dostupnost' do $30 \mathrm{~min}$ sa pozícia tohto uzla nezmení. Zmenila by sa iba v prípade, ak by sa hranica izolínií posunula na 20, resp. 10 min. Jedným z najväčších problémov pri meraní dostupnosti touto mierou je stanovenie intervalu validity zo získaných dát o vzdialenosti, resp. cestovnom čase $\mathrm{k}$ daným zariadeniam. 


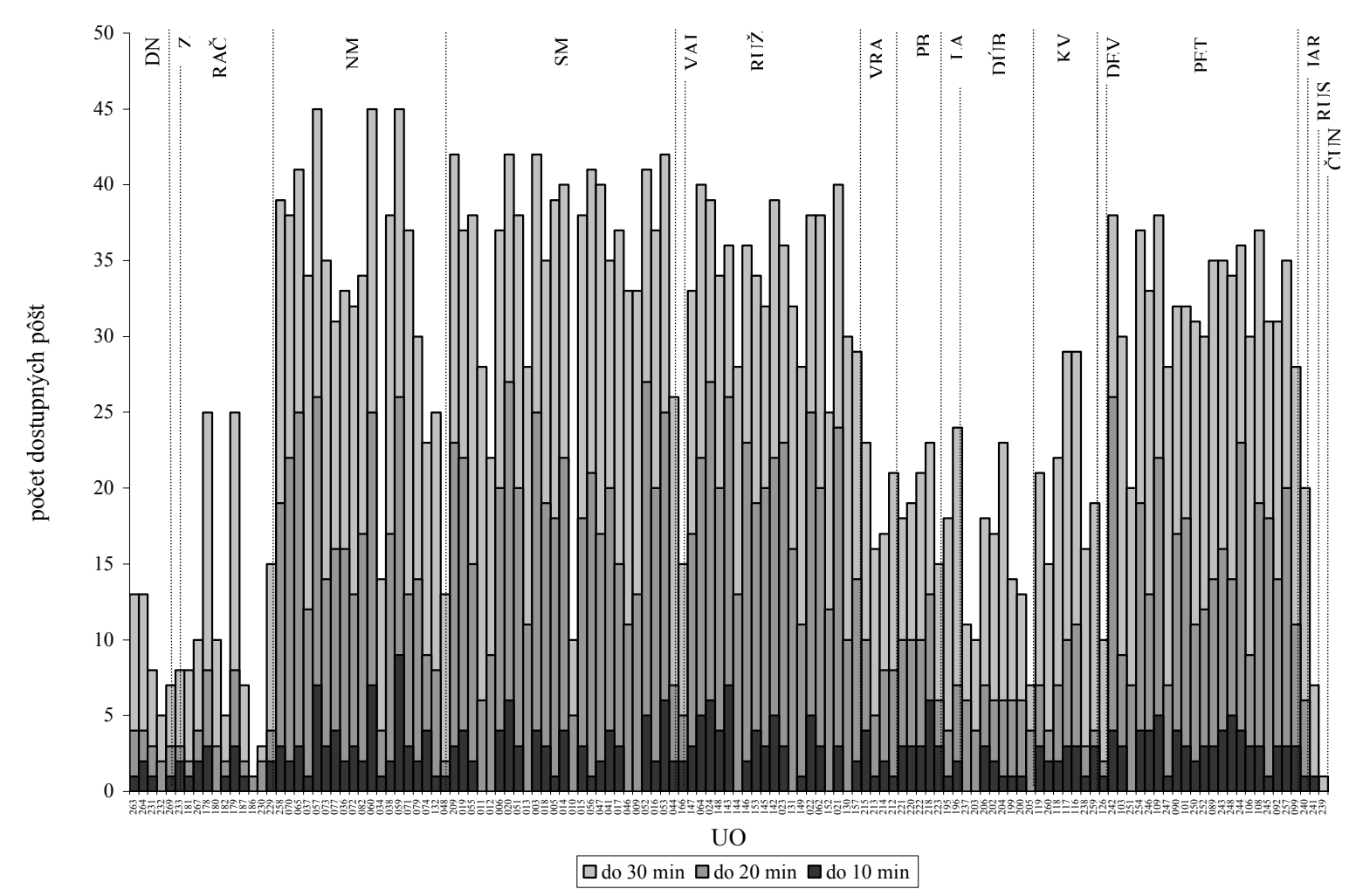

Graf 1. Dostupnost' pôšt na území mesta do vzdialenosti 10, 20 a 30 min (PET - Petržalka, NM - Nové Mesto a pod.).

Výsledky analýz poukázali na fakt, že neexistuje celková (univerzálna) miera dostupnosti [cf. 6, 14]. Pri aplikácii rôznych mier dostupnosti treba vychádzat' zo stanovených ciel’ov a determinácie výsledkov. Ako vhodný nástroj výskumu dostupnosti sa preukázala aplikácia nie jednej, ale viacerých alternatívnych mier dostupnosti [cf. 1], prípadne regionálna typizácia vychádzajúca $\mathrm{z}$ analýz priestorovej dostupnosti a zohl'adňujúca dané miery dostupnosti súčasne (Križan 2008). Možno súhlasit' s tvrdením K. Smoyer-Tomica a kol. [13, s. 288], že metódy použité na definovanie a meranie dostupnosti môžu signifikantne ovplyvnit' dané výsledky.

$\mathrm{Na}$ aplikovatel’nost' poznatkov získaných meraním dostupnosti poukazujú svojou definíciou R. Kulkarni a kol. [8, s. 421]: „dostupnost' je pre dopravu to, čo je tmavá hmota pre kozmológiu - neviditel'ná masa, ktorá v sebe uchováva kl’úč k mnohým kozmickým skladačkám. Paralelne ako čierna hmota, tak i kvantifikácia dostupnosti môže poskytovat' návod pre plánovanie infraštruktúry a rozvoja, smerovat' $\mathrm{k}$ rôznym vol'bám a radám...".

V príspevku neboli analyzované nepriestorové aspekty problematiky dostupnosti, čo predstavuje námet na budúce smerovanie výskumu.

\section{Literatúra}

[1] APPARICIO, P., CLOUTIER, M-S., SHEARMUR, R.: The case of Montréal's missing food deserts: Evaluation of accessibility to food supermarkets. International Journal of Health Geographics, 2007, 6, 4, (nečíslované).

[2] BRUINSMA, F.R., RIETVELD, P.: The accessibility of European cities: theoretical framework and comparison of approaches. Environment and Planning A, 1998, 30, 499521. 
[3] GUAGLIARDO, M.F.: Spatial accessibility of primary care: concepts, methods and challenges. International Journal of Health Geographics, 2004, 3, 3, (nečíslované).

[4] HALDEN, D.: Using accessibility measures to integrate land use and transport policy in Edinburgh and the Lothians. Transport Policy, 2002, 9, 4, 313-324.

[5] CHURCH, R.L., MARSTON, J.R.: Measuring Accessibility for People with a Disability. Geographical Analysis, 2003, 35, 1, 83-96.

[6] KRIŽAN, F.: Intraurbánna dostupnost' vybratých zariadení v Bratislave. Dizertačná práca, Bratislava: Prírodovedecká fakulta UK, str. 201.

[7] KRIŽAN, F., TOLMÁČI, L.: Meranie priestorovej dostupnosti pôšt na území mesta Bratislava pomocou percepčných mier dostupnosti (kvalitatívny prístup). Pošta, telekomunikácie a elektronický obchod, 2008, 3, 2, 33-42.

[8] KULKARNI, R.G., STOUGH, R.R., HAYNES, K.E.: Towards a percolation model of accessibility: an exploratory step. Computers, Environment and Urban Systems, 2000, 24, 5, 421-434.

[9] LÖFFLER, G.: Market areas - a methodological reflection on their boundaries. GeoJournal, 1998, 45, 4, 265-272.

[10] LIU, S., ZHU, X.: An Integrated GIS Approach to Accessibility Analysis. Transaction in GIS, 2004, 8, 1, 45-62.

[11] MICHNIAK, D.: Dostupnost' ako geografická kategória a jej význam pri hodnotení územno-správneho členenia Slovenska. Dizertačná práca, Bratislava: Geografický ústav SAV, str. 125.

[12] MICHNIAK, D.: Dostupnost' okresných miest na Slovensku. Geografický časopis, 2003, 55, 1, 21-39.

[13] SMOYER-TOMIC, K.E., HEWKO, J.N., HODGSON, M.J.: Spatial accessibility and equity of playgrounds in Edmonton, Canada. The Canadian Geographer, 2004, 48, 3, 287-302.

[14] TOLMÁČI, L.: Dostupnost' miest Slovenska. 1. vyd. MAPA Slovakia, Bratislava, 2002, str. 66, ISBN 80-89080-40-5.

[15] ZENK, S.N., A KOL.: Neighborhood Racial Composition, Neighborhood Poverty, and the Spatial Accessibility of Supermarkets in Metropolitan Detroit. American Journal of Public Health, 2005, 95, 4, 660-667.

\section{Grantová podpora}

Príspevok vznikol za finančnej podpory grantovej úlohy VEGA č. 1/3064/06. 


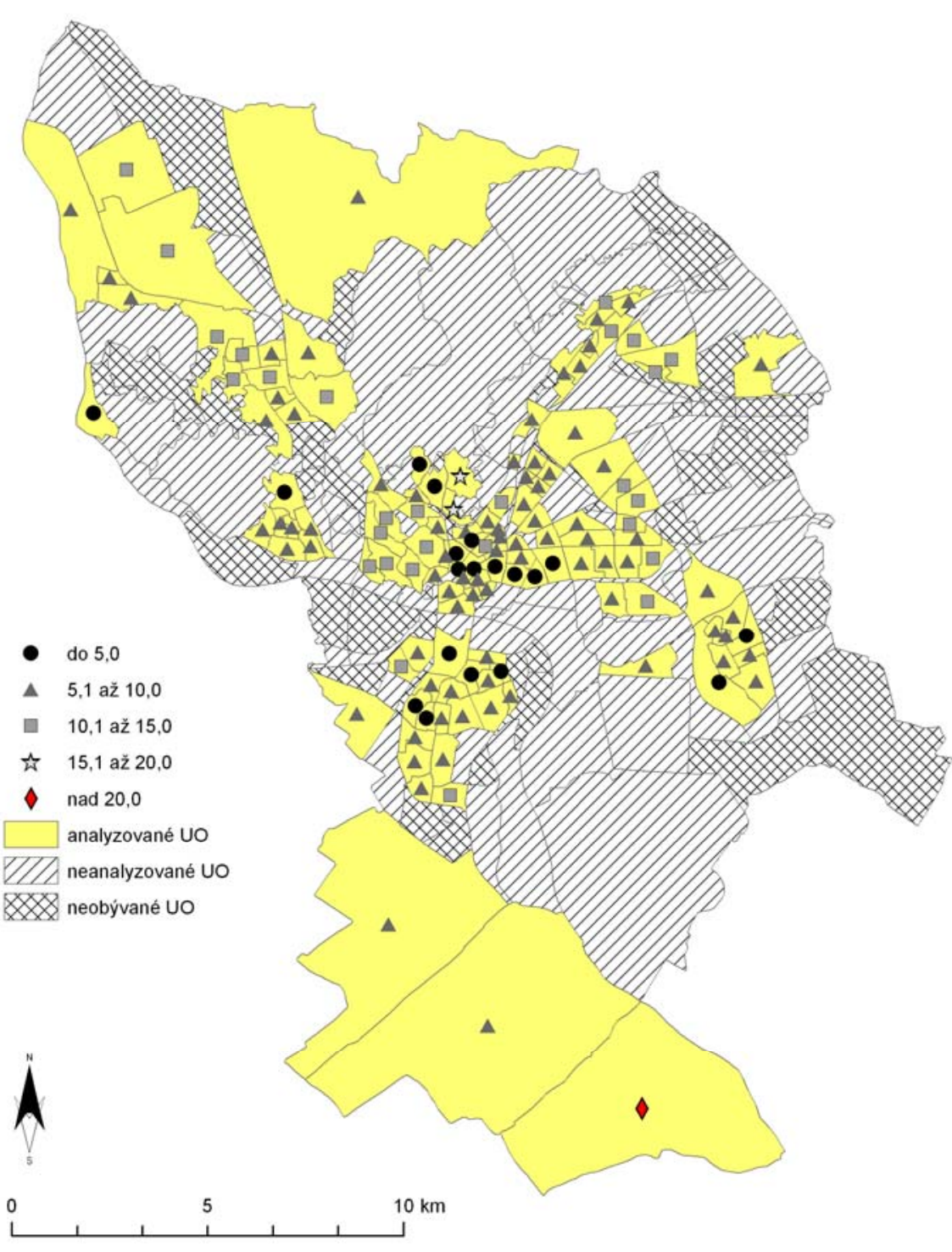

Obr. 3. Dostupnost' pôšt na území mesta meraná podl'a Dst1 [min].

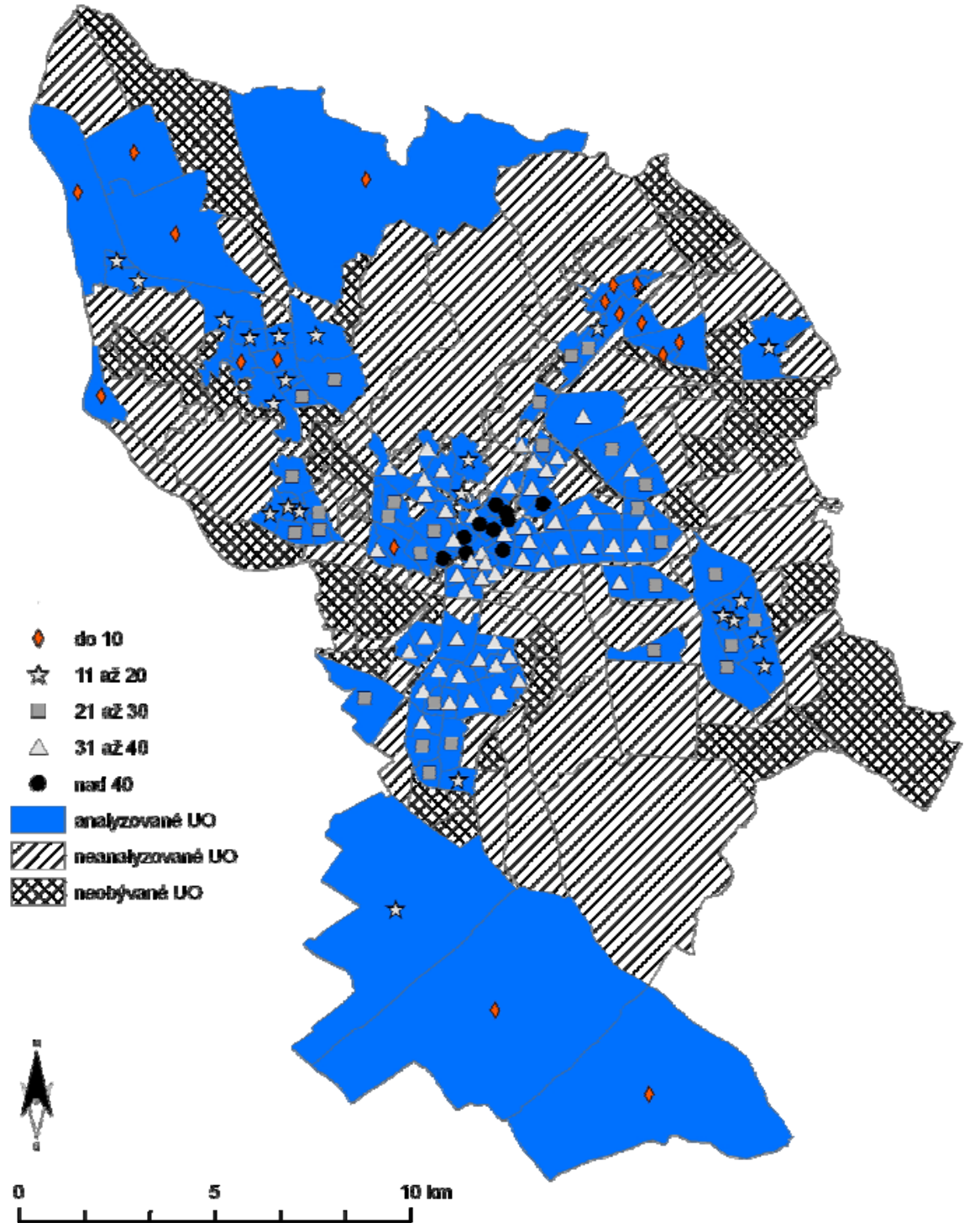

Obr. 4. Dostupnost' pôšt na území mesta meraná podla Dst2 [pošty]. 